\title{
Rare variants and de novo variants in mesial temporal lobe epilepsy with hippocampal sclerosis
} John K.L. Wong, PhD, Hongsheng Gui, PhD, Maxwell Kwok, BSc, Ping Wing Ng, MD, Colin H.T. Lui, MD,
Larry Baum, PhD, Pak Chung Sham, MD, PhD, Patrick Kwan, MD, PhD, and Stacey S. Cherny, PhD

Neurol Genet 2018;4:e245. doi:10.1212/NXG.0000000000000245

\section{Abstract}

\section{Objective}

We investigated the role of rare genetic variants and of de novo variants in the pathogenesis of mesial temporal lobe epilepsy related to hippocampal sclerosis (MTLE-HS).

\section{Methods}

Whole-exome sequencing (WES) was performed in patients with MTLE-HS and their unaffected parents (trios). Genes or gene sets that were enriched with predicted damaging rare variants in the patients as compared to population controls were identified. Patients and their parents were compared to identify whether the variants were de novo or inherited.

\section{Results}

After quality control, WES data from 47 patients ( 26 female), including 23 complete trios, were available for analysis. Compared with population controls, significant enrichment of rare variants was observed in SEC24B. Integration of gene set data describing neuronal functions and psychiatric disorders showed enrichment signal on fragile $\mathrm{X}$ mental retardation protein (FMRP) targets. Twenty-one de novo variants were identified, with many known to cause neuropsychiatric disorders. The FMRP-targeted genes also carried more de novo variants. Inherited compound heterozygous and homozygous variants were identified.

\section{Conclusions}

The genetic architecture underlying MTHE-HS is complex. Multiple genes carrying de novo variants and rare variants among FMRP targets were identified, suggesting a pathogenic role. MTLE-HS and other neuropsychiatric disorders may have shared biology.

\author{
Correspondence \\ Dr. Cherny \\ cherny@tauex.tau.ac.il or \\ Dr. Kwan \\ patrick.kwan@unimelb.edu.au or \\ Dr. Sham \\ pcsham@hku.hk
}

\section{RELATED ARTICLE}

\section{Editorial}

Whole-exome sequencing to disentangle the complex genetics of hippocampal sclerosis-temporal lobe epilepsy

Page e241

From the Centre for Genomic Sciences and Department of Psychiatry (J.K.L.W., H.G., L.B., P.C.S., S.S.C.), Li Ka Shing Faculty of Medicine, The University of Hong Kong; Department of
Medicine and Therapeutics (M.K., P.K.), The Chinese University of Hong Kong; Department of Medicine (P.W.N.), United Christian Hospital; Department of Medicine (C.H.T.L.), Queen
Elizabeth Hospital, Hong Kong, China; Departments of Medicine and Neurology (P.K.), The University of Melbourne, Royal Melbourne Hospital, Australia; Department of Epide-
miology and Preventive Medicine (S.S.C.) and Department of Anatomy and Anthropology (S.S.C.), Sackler Faculty of Medicine, Tel Aviv University, Israel; and The State Key Laboratory
of Brain and Cognitive Sciences (P.C.S., S.S.C.). Funding information and disclosures are provided at the end of the article. Full disclosure form information provided by the authors is available with the full text of this article at Neurology.org/NG.

The Article Processing Charge was funded by the University of Hong Kong.

This is an open access article distributed under the terms of the Creative Commons Attribution-NonCommercial-NoDerivatives License 4.0 (CC BY-NC-ND), which permits downloading and sharing the work provided it is properly cited. The work cannot be changed in any way or used commercially without permission from the journal. 


\section{Glossary}

ASD $=$ autism spectrum disorder ExAC $=$ Exome Aggregation Consortium; FMRP $=$ fragile X mental retardation protein; GWAS = genome-wide association study; HS = hippocampal sclerosis; IL = interleukin; MAF = minor allele frequency; MGI = Mouse Genome Informatics; $\mathbf{m G l u R}=$ metabotropic glutamate receptor; MTLE-HS = mesial temporal lobe epilepsy related to hippocampal sclerosis; $\mathbf{N M D A R}=\mathrm{NMDA}$ receptor; $\mathbf{S N P}=$ single nucleotide polymorphism; $\mathbf{W E S}=$ whole-exome sequencing.

Mesial temporal lobe epilepsy related to hippocampal sclerosis (MTLE-HS) is among the most drug-resistant types of focal epilepsy. ${ }^{1}$ Histologically, MTLE-HS is characterized by atrophy and astrogliosis of the amygdala, hippocampus, parahippocampal gyrus, and the entorhinal cortex. ${ }^{2}$ In drugresistant patients, resection of the sclerotic hippocampus and the surrounding mesial temporal structures can be an effective treatment $^{3}$; hence, MTLE-HS remains one of the most common indications for epilepsy surgery. ${ }^{4}$ Understanding the molecular basis of MTLE-HS may lead to identification of novel drug targets and alleviate the need for invasive treatment.

The pathogenesis of MTLE-HS is unknown. Several studies have investigated the role of common susceptibility variants in the pathogenesis of MTLE-HS. ${ }^{5}$ Early studies reported associations between single nucleotide polymorphisms (SNPs) in interleukin (IL)-1, PDYN, GABBR1, and PRNP and mesial temporal lobe epilepsy, but the results have been controversial. ${ }^{6}$ A recent genome-wide association study (GWAS) identified an association with SCN1A polymorphisms. ${ }^{7}$ However, a large heritability study of focal epilepsy suggested that common variants explained only $3 \%$ of heritability. ${ }^{8}$

Recently, whole-exome sequencing (WES) of 356 trios discovered 429 de novo variants in patients with epileptic encephalopathies, with recurrent mutations in 19 genes. ${ }^{5} \mathrm{We}$ hypothesized that, similar to other focal epilepsy syndromes, ${ }^{9}$ both rare and de novo variants may underlie the unexplained genetic susceptibility to MTLE-HS. WES was applied in a recent study of patients with a variety of common generalized and focal epilepsy syndromes, ${ }^{10}$ but trios were not examined. We performed WES on patients with MTLE-HS and some unaffected parents in this study.

\section{Methods}

\section{Study design}

We performed WES on patients with MTLE-HS and their unaffected parents. This enabled us to examine the effects of rare variants among all the patients by comparing with population controls and to identify genes containing de novo and inherited variants in trio-based analysis.

\section{Participants}

Patients with MTLE-HS (probands) and their parents were recruited from 3 regional hospitals (Prince of Wales Hospital, United Christian Hospital, and Queen Elizabeth Hospital) in Hong Kong. Inclusion criteria of probands were "pure" MTLE-
HS with concordant findings from seizure semiology, EEG (interictal and ictal recording during prolonged video EEG monitoring), MRI (1.5T or 3T) findings characteristic of hippocampal sclerosis (HS), and histologic confirmation of HS in patients who had undergone resective epilepsy surgery. ${ }^{11}$ All patients were ethnic Han Chinese with an age at onset of epilepsy of $\geq 2$ years. Patients were excluded if there was evidence of extratemporal lobe seizures, they had no history of seizure, had psychogenic nonepileptic seizures, or had other epileptogenic lesions identified on MRI. Parents of probands were eligible for inclusion if they did not have epilepsy or history of febrile seizure. Each participant provided either venous blood or saliva samples from which DNA was extracted for sequencing using standard protocols. A total of 48 patients with MTLE-HS were enrolled. Both parents were recruited for 23 patients, forming complete trios. The study was approved by the ethics committees of the participating hospitals. All participants or their legal guardians provided written informed consent.

\section{Population controls}

For the purpose of quality assessment and association testing, WES data from 692 Hong Kong Han Chinese participants (298 men and 394 women) were added to the calling set (Supplemental materials, links.lww.com/NXG/A55) (mean age: 41.1 years, range: $15-55$ years). They were participants in a population-based study investigating lumbar disc degeneration and did not have a history of developmental or neuropsychiatric disorders. ${ }^{12}$

\section{Standard protocol approvals, registrations, and patient consents}

The study was approved by the Joint Chinese University of Hong Kong-New Territories East Cluster Clinical Research Ethics Committee (ref. No. 2004.068 and 2004.268). All participants or their legal guardians provided written informed consent.

\section{Whole-exome sequencing and bioinformatics pipeline}

Detailed methodology for WES and the bioinformatics pipeline including quality control, variant calling, and in silico analysis, is provided in supplementary materials.

\section{Association analysis}

\section{Gene-based association tests}

Case-control analyses of rare variants (minor allele frequency $[\mathrm{MAF}]<1 \%$ in the 1000 Genomes Project Phase III, Exome Aggregation Consortium (ExAC), and dbSNP137 databases) included all the patients with MTLE-HS and population 
controls. Principle component analysis on the patient group $(\mathrm{N}=47)$ and control group $(\mathrm{N}=692)$ revealed no systematic bias between the 2 data sets (figure e-1, links.lww.com/NXG/ A55). Burden tests on rare damaging variants were performed per gene from the human RefGene database. Three criteria were adopted to select rare damaging variants within genes for the test: (1) single nucleotide variants with MAF $>1 \%$ in the 1000 Genomes Project Phase III, ExAC, and dbSNP137 databases were excluded; (2) missense and nonsense variants that passed quality control were used in the tests; and (3) only genes carrying 3 or more variants were included in the genebased association tests. A burden-style test from PLINK/SEQ (https://atgu.mgh.harvard.edu/plinkseq) was chosen for the purpose. The burden test was performed using 1,000,000 rounds of adaptive permutations. Multiple testing corrections were applied for the number of tested genes using the false discovery rate. ${ }^{13}$ Gene annotation and damaging variant prediction was performed using KGGSeq, which combines multiple prediction methods. ${ }^{14}$

\section{Set-based association tests}

For set-based association tests, we considered groups of genes with similar biological functions as the unit of testing (gene set). We first included a set of focal epilepsy candidate genes ${ }^{15}$ (table e-1, links.lww.com/NXG/A55). In addition, given the high prevalence of psychiatric disorders among patients with focal epilepsy, ${ }^{16}$ we curated additional gene sets by considering those of psychiatric disorders and of important neuronal functions (table e-2, links.lww.com/NXG/A55). Gene sets were obtained from the "Genebook" website(atgu.mgh.harvard.edu/ spurcell/genebook/genebook.cgi) previously used for a large-scale exome sequencing study of schizophrenia. ${ }^{17}$ The primary and secondary gene sets on the website cover 2,546 gene candidates involved in important systems of neuronal functions and previous studies of psychiatric disorders, including intellectual disability, schizophrenia, fragile X syndrome, and autism spectrum disorders (ASD). In particular, rare variants of fragile $\mathrm{X}$ mental retardation protein (FMRP)-targeted genes have been found to be enriched in multiple psychiatric disorders (fragile $\mathrm{X}, \mathrm{ASD}$, and schizophrenia). ${ }^{18}$ FMRP is encoded by the gene FMR1, an RNAbinding protein that regulates translation of synaptic genes for normal neurogenesis. ${ }^{19}$ We combined the 2 previously reported FMRP sets ${ }^{20,21}$ to better evaluate the importance of FMRP targets in MTLE-HS. The same criteria for variant selection and statistical tests as used for gene-based association were used for gene set-based association.

\section{Trio-based analysis}

To identify de novo and inherited variants attributed to MTLE-HS, trio-based analyses were performed in the subgroup of MTLE-HS patients with complete trios.

\section{De novo variants and gene set enrichment analysis}

KGGSeq was used for the discovery and annotation of de novo variants in the trios. The predicted damaging effects and variation intolerance scores were annotated per gene and per variant. In addition to the quality control described above, each de novo variant required a read depth $\geq 8$ to be called. Mutations found in any of the 3 population databases (dbSNP137, ExAC, or 1000 Genome phase III) were excluded. All de novo variants were validated by Sanger sequencing. The nonsynonymous to synonymous ratio was compared with other exome sequencing studies. The candidate focal epilepsy gene list (table e-1, links.lww.com/ NXG/A55) has been compared with our de novo variant gene list for overlaps. The 25 gene sets tested for rare variant association were also tested for enrichment of de novo variants by hypergeometric test, so as to assess whether the same biological network was disrupted among the de novo genes.

\section{Inherited variant analysis: homozygotes and compound heterozygotes}

To investigate the effect of heterozygous and homozygous (double hit) events, genes carrying $\geq 2$ mutations in heterozygous and homozygous configurations were summarized. At least 1 hit inherited from each unaffected parent is required to fit the sporadic nature of the recruited samples. Rare variants at MAF $\leq 1 \%$ (in the 1000 Genomes Project Phase III, ExAC, and dbSNP137 databases) were considered in the analysis. We considered the following scenarios of genes carrying double hit variants, which are rare/absent in the population: (1) candidate genes suggested by functional databases (Phenolyzer and SynaptomeDB) and with adjusted $p$ values $<0.05$; (2) both contributing variants are nonsense and not found among phased controls (Genome of the Netherlands project suggested double knockout by Lossof-Function variants are very rare $)^{22}$; and/or (3) genes with de novo variants carried by the patients with MTLE-HS. Details of each approach are described in Supplemental materials, links.lww.com/NXG/A55. The recurrences in the subsequent gene list were further investigated for their relevance to MTLE-HS.

\section{Integrative genomic annotation}

To investigate whether the gene sets suggested by the association tests are enriched at the transcriptome level, we reviewed published expression studies on hippocampal tissues of patients with MTLE-HS to derive an intersected list of dysregulated genes (table e-3, links.lww.com/NXG/A55). Seven expression studies were identified after excluding studies on other types of epilepsies. Genes reported by at least 2 studies were included in the gene list. The genes were tested for enrichment with the 25 candidate gene sets derived from the "Genebook" website. Hypergeometric tests were performed, where $p$ values were corrected for the number of tests ( 25 sets $\times 7$ studies).

To investigate the functional relevance of the candidate genes carrying de novo variants, we queried the gene list against Mouse Genome Informatics (MGI) and ClinVar. ${ }^{23}$ Genes reported to cause any neural abnormalities in knockout mouse models or by human genetic studies were tabulated. 


\section{Results}

\section{Participants}

A total of 48 patients with MTLE-HS were enrolled. Sequence data from 1 patient did not pass quality control and was excluded (supplemental data, links.lww.com/NXG/A55), leaving 47 patients (26 female) for further analysis. The characteristics of the patients are shown in table 1. The median age at onset of epilepsy was 17.7 years (range 1.5-43 years), and the median age of recruitment was 39.5 years (range 13-57.4 years). There were equal numbers of patients with left and right HS (21 patients each); 5 patients had bilateral disease. Thirty patients with unilateral drug-resistant MTLE-HS had undergone epilepsy surgery (anterior temporal lobectomy and amygdalohippocampectomy). Seizure onset was confirmed on ictal video EEG recording in all patients before surgery. Histology confirmed HS in the resected hippocampus in all patients. Nineteen were seizurefree after surgery. Both parents were recruited for 23 patients, forming complete trios. None of the parents had a history of epilepsy or febrile seizure. All probands and parents were of Han Chinese descent.

\section{Association analysis}

\section{Gene-based and set-based association tests}

Gene-based $p$ values are shown in table 2. The SEC24B gene remained significant after correction for multiple testing $(q<$ $0.041,5,154$ genes). The association was contributed by 4 predicted damaging variants, 3 of which were found in the patients and 1 in the population controls.

Table 3 shows results of the set-based tests using 25 gene sets. After correction for multiple comparisons, significant enrichment was observed in the FMRP-related gene sets. The bigger FMRP set ${ }^{20}$ achieved a higher significance level, including all rare variants in the comparison $\left(p<3.88 \times 10^{-4}\right)$. When restricting to the rare predicted damaging variants, the unified set of 2 FMRP gene sets ${ }^{20,21}$ also achieved statistical significance $\left(p<2.89 \times 10^{-4}\right)$. There was no significant enrichment for rare variants in the candidate focal epilepsy gene set.

\section{Trio-based analysis}

\section{De novo variants}

In total, 27 de novo variants were identified. One variant was excluded from validation because of technical difficulties. Among the remaining 26 variants, 21 were validated by Sanger sequencing. Therefore, our analysis pipeline achieved a true positive rate of $81 \%(21 / 26)$. There were no recurrent de novo mutated genes. The validated de novo mutations were found in 13 patients ( 8 had 1, 2 had 2, and 3 had 3 mutations). Of the 21 validated de novo mutations, 18 were nonsynonymous and 3 were synonymous (table 4 ). The nonsynonymous to synonymous variant ratio of all de novo variants was $6: 1(p<0.22)$, which is higher than the neutral rate reported in other studies $(2.8: 1)^{24}$ and is higher than that reported in patients with other neuropsychiatric disorders, including intellectual disability (5.6:1), ASD (3.1:1), and schizophrenia $(5.1: 1)^{24}$ (table e-4, links.lww.com/NXG/ A55). Two of the patients with de novo variants have a family history of epilepsy, implying that, as expected, not all of the de novo variants cause epilepsy.

The list of the 18 genes carrying the nonsynonymous de novo variants was compared with 3 studies investigating de novo variants in different neuropsychiatric disorders (epileptic encephalopathies, ${ }^{25} \mathrm{ASD},{ }^{26}$ and schizophrenia ${ }^{24}$ ). We found that 5 of 18 genes were reported by one of the studies, and 3 genes (ROBO4, NLGN3, and CEP17OB) were found to overlap with the ASD study (table 4). However, none of the 18 genes affected by nonsynonymous de novo variants was found in the focal epilepsy gene set (table e-1, links.lww.com/NXG/A55).

\section{Gene set enrichment analysis for de novo variants}

The enrichment test suggests that the FMRP-targeted genes also carried more de novo variants in the patients with MTLEHS, which is in agreement with the association results mentioned above (table e-5, links.lww.com/NXG/A55). Although testing of the 2 FMRP-targeted gene sets ${ }^{20,21}$ separately were not significant, the merged FMRP set achieved a significant $p$ value $(p<0.0013)$.

\section{Inherited variants: homozygotes and compound heterozygotes}

We assessed the patients for inherited damaging variants acting in a recessive manner, either as compound heterozygotes or homozygotes. Genes fulfilling such criteria were considered to be carrying "double-hit" variants. For loss-offunction variants, we considered all rare events (MAF $<1 \%$ ). Only 1 gene, $P 2 R X 7$, was identified, harboring a homozygous nonsense variant (NM 002562:c.1591G>T:p.E531*) in a single patient. The mutation was validated by Sanger sequencing.

For missense variants, we considered genes carrying double hit variants, which are recurrent in MTLE-HS or present in the de novo gene list. In addition to restricting MAF to $1 \%$ in population databases, we used 3 criteria described in the Methods section to identify 3 genes carrying missense variants as either homozygous or compound heterozygous: $C E P 170 B$, UBR4, and CALHM1.

We found 2 patients carrying homozygous or compound heterozygous rare variants in CEP170B. Among 4 of the contributed variants, one of them is a de novo variant. The 2 compound heterozygous variants were validated. One of the probands carrying a compound heterozygous variant in $C E P 170 B$ had a reported family history of epilepsy (sibling and son) (table e-6, links.lww.com/NXG/A55).

\section{Integrative genomic annotation}

Comparison between the 25 gene sets used in the association tests and published transcriptomic studies of MTLE-HS 
Table 1 Clinical characteristics of patients with mesial temporal lobe epilepsy related to hippocampal sclerosis and their corresponding genes reported Trios group (included in association analysis and trio-based analysis)

\begin{tabular}{|c|c|c|c|c|c|c|c|c|c|c|c|}
\hline $\begin{array}{l}\text { Participant } \\
\text { no. }\end{array}$ & Sex & $\begin{array}{l}\text { Age at } \\
\text { recruitment }\end{array}$ & $\begin{array}{l}\text { Age at } \\
\text { onset }\end{array}$ & $\begin{array}{l}\text { Duration of } \\
\text { epilepsy }\end{array}$ & $\begin{array}{l}\text { History of } \\
\mathrm{FS}^{1}\end{array}$ & $\begin{array}{l}\text { Epilepsy } \\
\text { surgery }\end{array}$ & $\begin{array}{l}\text { Surgical } \\
\text { outcome }^{a}\end{array}$ & Lateralization & $\begin{array}{l}\text { Family history of } \\
\text { epilepsy or FS }\end{array}$ & $\begin{array}{l}\text { Inheritance } \\
\text { model }^{\mathbf{b}}\end{array}$ & $\begin{array}{l}\text { Gene } \\
\text { name }\end{array}$ \\
\hline 5 & Female & 34.3 & 6 & 28.3 & Yes & No & - & L & $\begin{array}{l}\text { Paternal granduncles } \\
\text { (epilepsy) }\end{array}$ & - & - \\
\hline
\end{tabular}

\begin{tabular}{lllllll}
\hline $\mathbf{8}$ & Male & 57.4 & 29 & 28.4 & No & No \\
\hline $\mathbf{9}$ & Female & 52.8 & 34 & 18.8 & No & No
\end{tabular}

No

$-$

R N

$\mathrm{N}$

\begin{tabular}{|c|c|c|c|c|c|c|c|c|c|}
\hline 12 & Male & 42 & 13 & 29 & No & No & - & B & $\mathrm{N}$ \\
\hline 15 & Female & 25.5 & 12 & 13.5 & No & Yes & $P$ & $\mathrm{~L}$ & $\mathrm{~N}$ \\
\hline 17 & Male & 39.7 & 27 & 12.7 & No & Yes & $\mathrm{G}$ & $\mathrm{R}$ & $\mathrm{N}$ \\
\hline 19 & Male & 50.3 & 14 & 36.3 & Yes & No & - & $\mathrm{L}$ & $\mathrm{N}$ \\
\hline
\end{tabular}

\begin{tabular}{|c|c|c|c|c|c|c|c|c|c|}
\hline 12 & Male & 42 & 13 & 29 & No & No & - & B & $\mathrm{N}$ \\
\hline 15 & Female & 25.5 & 12 & 13.5 & No & Yes & $P$ & L & $\mathrm{N}$ \\
\hline 17 & Male & 39.7 & 27 & 12.7 & No & Yes & G & $\mathrm{R}$ & $\mathrm{N}$ \\
\hline 19 & Male & 50.3 & 14 & 36.3 & Yes & No & - & L & $\mathrm{N}$ \\
\hline
\end{tabular}

\begin{tabular}{|c|c|c|c|c|c|c|c|c|c|}
\hline 12 & Male & 42 & 13 & 29 & No & No & - & $B$ & $\mathrm{~N}$ \\
\hline 15 & Female & 25.5 & 12 & 13.5 & No & Yes & $P$ & L & $\mathrm{N}$ \\
\hline 17 & Male & 39.7 & 27 & 12.7 & No & Yes & $\mathrm{G}$ & $\mathrm{R}$ & $\mathrm{N}$ \\
\hline 19 & Male & 50.3 & 14 & 36.3 & Yes & No & - & $L$ & $\mathrm{~N}$ \\
\hline
\end{tabular}

$+\frac{10}{20}$

\begin{tabular}{|c|c|c|c|c|c|c|c|c|c|c|c|}
\hline & & & & & & & & & & De novo & $C D C 42 E P 1$ \\
\hline 21 & Female & 40.9 & 17 & 23.9 & No & No & - & B & $\mathrm{N}$ & - & - \\
\hline 22 & Female & 33.7 & 17 & 16.7 & Yes & Yes & $\mathrm{G}$ & $\mathrm{R}$ & $\mathrm{N}$ & - & - \\
\hline \multirow[t]{2}{*}{24} & Male & 31.1 & 23 & 7.9 & Yes & No & - & L & $\mathrm{N}$ & De novo & NBEAL1 \\
\hline & & & & & & & & & & $\mathrm{CH}$ & UBR4 \\
\hline 25 & Male & 35.2 & 31 & 3.7 & No & Yes & G & $\mathrm{R}$ & $\mathrm{N}$ & Homozygous & CEP170B \\
\hline \multirow[t]{2}{*}{26} & Female & 25.6 & 2.3 & 23.3 & Yes & Yes & $\mathrm{P}$ & $\mathrm{L}$ & $\mathrm{N}$ & De novo & NPC1L1 \\
\hline & & & & & & & & & & Rare burden & $S E C 24 B$ \\
\hline 28 & Female & 21.9 & 13 & 8.6 & No & Yes & G & $\mathrm{R}$ & $\mathrm{N}$ & - & - \\
\hline 30 & Female & 41.1 & 12 & 29.3 & Yes & Yes & G & $B$ & $\mathrm{~N}$ & De novo & ANXA6 \\
\hline 33 & Male & 17.6 & 6 & 11.3 & No & Yes & G & $\mathrm{R}$ & $\mathrm{N}$ & $\mathrm{CH}$ & CALHM1 \\
\hline 34 & Female & 31.3 & 17 & 14.4 & No & Yes & G & $\mathrm{L}$ & $\mathrm{N}$ & De novo & NLGN3 \\
\hline
\end{tabular}


Table 1 Clinical characteristics of patients with mesial temporal lobe epilepsy related to hippocampal sclerosis and their corresponding genes reported (continued) Trios group (included in association analysis and trio-based analysis)

\begin{tabular}{|c|c|c|c|c|c|c|c|c|c|c|c|}
\hline $\begin{array}{l}\text { Participant } \\
\text { no. }\end{array}$ & Sex & $\begin{array}{l}\text { Age at } \\
\text { recruitment }\end{array}$ & $\begin{array}{l}\text { Age at } \\
\text { onset }\end{array}$ & $\begin{array}{l}\text { Duration of } \\
\text { epilepsy }\end{array}$ & $\begin{array}{l}\text { History of } \\
\mathrm{FS}^{1}\end{array}$ & $\begin{array}{l}\text { Epilepsy } \\
\text { surgery }\end{array}$ & $\begin{array}{l}\text { Surgical } \\
\text { outcome }^{a}\end{array}$ & Lateralization & $\begin{array}{l}\text { Family history of } \\
\text { epilepsy or FS }\end{array}$ & $\begin{array}{l}\text { Inheritance } \\
\text { model }^{\mathbf{b}}\end{array}$ & $\begin{array}{l}\text { Gene } \\
\text { name }\end{array}$ \\
\hline 37 & Female & 31.5 & 15 & 16.6 & Yes & No & - & $\mathrm{R}$ & N & De novo & SBSPON \\
\hline \multirow[t]{2}{*}{39} & Female & 46.4 & 7 & 39.6 & Yes & No & - & L & N & De novo & BAIAP2 \\
\hline & & & & & & & & & & De novo & RASEF \\
\hline \multirow[t]{2}{*}{40} & Female & 47 & 36 & 10.9 & No & No & - & $\mathrm{R}$ & $\begin{array}{l}\text { Elder brother (epilepsy) } \\
\text { and son (febrile } \\
\text { convulsion) }\end{array}$ & De novo & $\mathrm{ROBO} 4$ \\
\hline & & & & & & & & & & $\mathrm{CH}$ & CEP170B \\
\hline 41 & Male & 25.9 & 6 & 19.8 & Yes & No & - & L & $\begin{array}{l}\text { Elder sister (febrile } \\
\text { convulsion) }\end{array}$ & - & - \\
\hline \multirow[t]{2}{*}{43} & Male & 53.6 & 10 & 43.8 & Yes & No & - & $\mathrm{R}$ & $\begin{array}{l}\text { Younger sister } \\
\text { (epilepsy) }\end{array}$ & De novo & PLEC \\
\hline & & & & & & & & & & De novo & TACC2 \\
\hline 44 & Male & 42.9 & 14 & 28.9 & No & No & - & $\mathrm{R}$ & N & De novo & BHLHE4O \\
\hline 45 & Male & 49.3 & 21 & 27.9 & No & No & - & L & $\mathrm{N}$ & - & - \\
\hline
\end{tabular}

Cases-only group (included in association analysis)

\begin{tabular}{|c|c|c|c|c|c|c|c|c|c|c|c|}
\hline $\begin{array}{l}\text { Participant } \\
\text { no. }\end{array}$ & Sex & $\begin{array}{l}\text { Age at } \\
\text { recruitment }\end{array}$ & $\begin{array}{l}\text { Age at } \\
\text { onset }\end{array}$ & $\begin{array}{l}\text { Duration of } \\
\text { epilepsy }\end{array}$ & $\begin{array}{l}\text { History of } \\
\text { FS }\end{array}$ & $\begin{array}{l}\text { Epilepsy } \\
\text { surgery }\end{array}$ & $\begin{array}{l}\text { Surgical } \\
\text { outcome }^{a}\end{array}$ & Lateralization & $\begin{array}{l}\text { Family history of } \\
\text { epilepsy or FS }\end{array}$ & $\begin{array}{l}\text { Inheritance } \\
\text { model }^{\mathbf{b}}\end{array}$ & $\begin{array}{l}\text { Gene } \\
\text { name }\end{array}$ \\
\hline 1 & Female & 42.4 & 29 & 13.4 & No & Yes & $P$ & B & $\mathrm{N}$ & - & - \\
\hline 2 & Female & 25.7 & 19 & 6.7 & No & Yes & G & $\mathrm{R}$ & N & - & - \\
\hline 3 & Female & 56.2 & 43 & 13.2 & No & Yes & P & $\mathrm{R}$ & $\begin{array}{l}\text { Younger sister } \\
\text { (epilepsy) }\end{array}$ & - & - \\
\hline 4 & Female & 38.7 & 9 & 29.7 & Yes & Yes & $P$ & $\mathrm{R}$ & $\mathrm{N}$ & - & - \\
\hline 6 & Female & 35.1 & 6 & 29.1 & No & Yes & G & L & N & - & - \\
\hline 7 & Female & 49 & 6 & 43 & No & Yes & G & L & N & - & - \\
\hline 10 & Female & 52.2 & 30 & 22.2 & No & No & - & L & $\mathrm{N}$ & - & - \\
\hline 11 & Female & 39.5 & 10 & 29.5 & Yes & Yes & G & $R$ & $N$ & - & - \\
\hline 13 & Male & 46.3 & 33 & 13.3 & No & Yes & P & L & $N$ & - & - \\
\hline
\end{tabular}




\begin{tabular}{|c|c|c|c|c|c|c|c|c|c|c|c|}
\hline \multicolumn{12}{|c|}{ Cases-only group (included in association analysis) } \\
\hline $\begin{array}{l}\text { Participant } \\
\text { no. }\end{array}$ & Sex & $\begin{array}{l}\text { Age at } \\
\text { recruitment }\end{array}$ & $\begin{array}{l}\text { Age at } \\
\text { onset }\end{array}$ & $\begin{array}{l}\text { Duration of } \\
\text { epilepsy }\end{array}$ & $\begin{array}{l}\text { History of } \\
\text { FS }\end{array}$ & $\begin{array}{l}\text { Epilepsy } \\
\text { surgery }\end{array}$ & $\begin{array}{l}\text { Surgical } \\
\text { outcome }^{a}\end{array}$ & Lateralization & $\begin{array}{l}\text { Family history of } \\
\text { epilepsy or FS }\end{array}$ & $\begin{array}{l}\text { Inheritance } \\
\text { model }^{\mathbf{b}}\end{array}$ & $\begin{array}{l}\text { Gene } \\
\text { name }\end{array}$ \\
\hline 14 & Male & 42.7 & 16 & 26.7 & Yes & Yes & G & L & $\mathrm{N}$ & - & - \\
\hline 16 & Male & 33 & 17 & 16 & No & Yes & G & $\mathrm{R}$ & $\mathrm{N}$ & - & - \\
\hline 18 & Female & 36.1 & 24 & 12.1 & Yes & Yes & $\mathrm{P}$ & L & $\mathrm{N}$ & - & - \\
\hline 20 & Female & 23.3 & 13 & 10.3 & No & Yes & G & L & $\mathrm{N}$ & - & - \\
\hline 23 & Male & 51.6 & 30 & 21.7 & No & Yes & G & $\mathrm{R}$ & $\mathrm{N}$ & - & - \\
\hline 27 & Female & 30.7 & 23 & 7.9 & Yes & No & - & B & $\begin{array}{l}\text { Maternal aunt } \\
\text { (epilepsy) }\end{array}$ & - & - \\
\hline 29 & Female & 53.6 & 7 & 46.4 & No & Yes & G & L & $N$ & - & - \\
\hline 31 & Female & 15 & 1 & 13.5 & No & Yes & G & $\mathrm{R}$ & $\mathrm{N}$ & Rare burden & SEC24B \\
\hline 32 & Male & 13 & 9 & 3.5 & No & Yes & - & $R$ & $\mathrm{~N}$ & - & - \\
\hline 35 & Male & 55.1 & 41 & 14.6 & No & Yes & $P$ & L & $\mathrm{N}$ & - & - \\
\hline 38 & Male & 39.3 & 6 & 33.3 & No & Yes & G & $R$ & $N$ & - & - \\
\hline 42 & Female & 37.5 & 7 & 30.9 & No & No & - & $R$ & $\mathrm{~N}$ & - & - \\
\hline 46 & Male & 42.3 & 35 & 7 & Yes & No & - & L & $\mathrm{N}$ & - & - \\
\hline 47 & Male & 28 & NA & NA & Yes & Yes & G & L & $\mathrm{N}$ & $\mathrm{CH}$ & UBR4 \\
\hline 48 & Male & 43.6 & NA & NA & No & Yes & $P$ & $\mathrm{R}$ & $\mathrm{N}$ & - & - \\
\hline
\end{tabular}

Abbreviations: - = not applicable; $\mathrm{B}=$ bilateral; $\mathrm{CH}$ = compound heterozygous; $\mathrm{FS}=$ febrile seizure; $\mathrm{L}=$ left; $\mathrm{R}=$ right.

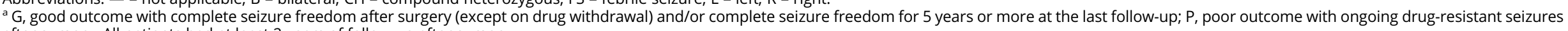
b The 3 models of inherithad at least 2 years of follow-up after surgery. 
Table 2 Results of the gene-based association test

\begin{tabular}{llll}
\hline Gene & $\begin{array}{l}\text { Tested } \\
\text { variants }\end{array}$ & $\boldsymbol{p}$ Value & $\begin{array}{l}\text { Corrected } \\
\boldsymbol{p} \text { value }\end{array}$ \\
\hline SEC24B & 4 & $8.00 \times 10^{-6}$ & 0.041 \\
\hline SUCO & 5 & $2.70 \times 10^{-5}$ & 0.139 \\
\hline MAN1C1 & 4 & $6.15 \times 10^{-5}$ & 0.317 \\
\hline TRDMT1 & 3 & $3.83 \times 10^{-4}$ & 1 \\
\hline KIF3A & 3 & $6.12 \times 10^{-4}$ & 1 \\
\hline SS18L1 & 5 & $6.19 \times 10^{-4}$ & 1 \\
\hline QSER1 & 5 & $6.49 \times 10^{-4}$ & 1 \\
\hline BBS5 & 3 & $9.33 \times 10^{-4}$ & 1 \\
\hline CLCN1 & 7 & $9.73 \times 10^{-4}$ & 1 \\
\hline ACMSD & 3 & 0.0010 & 1 \\
\hline GALNTL5 & 3 & 0.0010 & 1 \\
\hline NCKAP5 & 6 & 0.0011 & 1 \\
\hline
\end{tabular}

Genes carrying 3 or more variants were included in the gene-based association tests $(5,154$ genes tested). The gene-based burden test results of 47 mesial temporal lobe epilepsy related to hippocampal sclerosis cases vs 692 controls.

showed that the NMDA receptor (NMDAR), PSD, FMRP, and metabotropic glutamate receptor (mGluR) 5 gene sets are significantly enriched in the differentially expressed genes (table e-3, links.lww.com/NXG/A55).

Candidate genes in the de novo list were queried against the ClinVar database, and none was known to be associated with epilepsy. The MGI database showed a myriad of genes associated with the abnormal nervous system phenotype in knockout mice. Six of the 18 genes in our de novo list were also listed by MGI, suggesting that their knockout mice model might produce aberrant nervous system phenotypes (BHLHE40, TACC2, ROBO4, GRASP, BAIAP2, and NLGN3); keywords such as "abnormal nervous system development" and "disrupted synaptic transmission" were frequently observed in the list.

\section{Discussion}

In this study, we have identified de novo variants and rare variants possibly involved in the genetic risks of MTLE-HS. Consideration of rare variants in our WES and that of differentially expressed genes in resected hippocampal tissues both suggest that FMRP targets play a potential role in the pathogenesis of MTLE-HS. In addition, we have identified rare variants in SEC24B, which might be associated with the disease. ${ }^{27}$

FMRP, encoded by the FMR1 gene, regulates a number of genes, many of which are expressed in the brain and are implicated in psychiatric disorders. ${ }^{28}$ It is important that the
MTOR gene was reported to be one of the top 5 FMRPregulated targets; for example, the expression of FMR1 was shown to reduce the mTOR protein level by $30 \%$ in vitro. ${ }^{20}$ The mTOR pathway was found to be inactive in sclerotic hippocampus ${ }^{29}$ and is believed to induce inflammatory reactions in neurons through the PI3K/Akt/mTOR signaling pathway in patients with MTLE-HS. ${ }^{30}$ Our case-control rare variant association study suggested that FMRP targets are significantly associated with MTLE-HS $\left(p<3.88 \times 10^{-4}\right)$. It is plausible that the dysregulation of mTOR could be caused by gene mutations of the FMRP pathway. The enrichment test of de novo variants among MTLE-HS cases also suggests that mutations could be introduced to FMRP targets by spontaneous mutations. Both transcriptome and genomic analysis highlighted the importance of FMRP targets in MTLE-HS pathogenesis. However, the size of the FMRP gene set is a potential bias. For the candidate focal epilepsy gene set test, we observed no significant enrichment, but the candidate gene list in table-e1 (links.lww.com/NXG/A55) may be incomprehensive.

Expression data further revealed the complexity of dysregulated pathways related to neural functions in MTLE-HS. In addition to FMRP targets, the results also suggested that mGluR5, PSD, and NMDAR-associated gene sets may play roles in the pathogenesis of MTLE-HS. These gene sets are important for dendritic development and function; hence, they could also be candidate genes of MTLE-HS.

The case-control gene-based association analysis identified SEC24B as a potential candidate gene for MTLE-HS. Little is known about the function of this gene, although mutations of SEC24B have been reported to cause neural tube development defects in humans and knockout mice. ${ }^{31}$ How this relates to the pathogenesis of MTLE-HS is unknown. Targeted studies on our reported candidate genes from the association analysis could be performed to confirm the association signal. Animal models may be used to verify the effect of the observed variants on neural development. Apart from the investigation of well-defined epilepsy subgroups, meta-analysis by aggregating next-generation sequencing studies in consortium settings could be pursued in the light of gaining discovery power. The approach was demonstrated by an International League Against Epilepsy Consortium ${ }^{5}$ GWAS studies, which reported associations with genes such as SCN1A. However, we did not detect any association signal and de novo variants in the coding region of SCN1A. This could be due to the risk that SNPs of MTLE-HS are more frequently found within the promoter region of SCN1A. A common variant association study on focal epilepsy also suggested the risk that SNPs of SCN1A could act through its expression modulation. ${ }^{7}$

By screening candidate genes carrying de novo variants, we identified another 2 patients carrying compound heterozygous or homozygous rare variants in the gene CEP170B. A total of 3 patients carried either inherited or de novo $C E P 170 B$ variants. 
Table 3 Results of the gene set burden test

\begin{tabular}{|c|c|c|c|}
\hline Set $^{a}$ & Genes & $\begin{array}{l}\text { Damaging } \\
p \text { value }\end{array}$ & All $p$ value \\
\hline FMRP-Ascano + FMRP-Darnell & 1,557 & $2.89 \times 10^{-4}$ & $2.15 \times 10^{-3}$ \\
\hline FMRP-Ascano & 939 & $3.15 \times 10^{-3}$ & $3.88 \times 10^{-4}$ \\
\hline scz-denovo-lof & 87 & 0.013 & 0.027 \\
\hline ARC complex & 28 & 0.025 & 0.077 \\
\hline calcium-channel & 26 & 0.033 & 0.013 \\
\hline FMRP-Darnell & 788 & 0.040 & 0.450 \\
\hline PSD-95 & 65 & 0.040 & 0.167 \\
\hline PSD & 685 & 0.059 & 0.303 \\
\hline kirov-denovo-cnv & 234 & 0.118 & 0.048 \\
\hline mGluR5 & 39 & 0.220 & 0.360 \\
\hline ID-candidates & 196 & 0.289 & 0.200 \\
\hline ASD-candidates & 112 & 0.357 & 0.538 \\
\hline FMRP-ASD-overlap-Ascano & 93 & 0.538 & 1.000 \\
\hline psych-cnv & 346 & 0.538 & 0.833 \\
\hline ASD-49-gene-network & 49 & 0.583 & 0.833 \\
\hline scz-denovo-nonsyn & 611 & 0.583 & 0.120 \\
\hline ASD-74-gene-network & 74 & 0.600 & 0.282 \\
\hline ID-denovo-nonsyn & 132 & 0.667 & 0.833 \\
\hline ASD-denovo-nonsyn & 743 & 0.714 & 1.000 \\
\hline CHD8-network & 6 & 0.714 & 0.018 \\
\hline $\operatorname{miR}-137$ & 446 & 0.714 & 0.450 \\
\hline scz-gwas & 479 & 0.714 & 0.370 \\
\hline NMDAR network & 61 & 0.833 & 0.833 \\
\hline ASD-denovo-lof & 128 & 1.000 & 0.833 \\
\hline ID-denovo-Iof & 30 & 1.000 & 0.833 \\
\hline
\end{tabular}

Abbreviations: $A R C=$ activity-regulated cytoskeleton-associated protein ASD = autism spectrum disorder; FMRP = fragile $X$ mental retardation protein; ID = intellectual disability; mGluR = metabotropic glutamate receptor; NMDAR = NMDA receptor; $P S D=$ postsynaptic density .

Bold: significant after multiple testing correction for 48 sets.

The gene set burden test results of 47 mesial temporal lobe epilepsy related to hippocampal sclerosis cases vs 692 controls.

a For detail of gene sets, see table e-2, links.Iww.com/NXG/A55.

${ }^{\mathrm{b}}$ Test on rare and predicted damaging variants.

'Test on all rare variants.

Notably, 1 patient who carried compound heterozygous variants on CEP170B also showed a family history of MTLE-HS. We could not confirm whether the affected family members also carry 1 or more copies of these $C E P 170 B$ variants, as they have not been tested. The remaining 2 cases affected by recessive $C E P 170 B$ variants appear to be sporadic. De novo variants in $C E P 170 B$ have also been reported in patients with ASD. According to ProteomicsDB, ${ }^{32}$ protein expression of CEP170B has been detected mostly in the fetal brain and adult brain. The function of $C E P 170 B$ is not well characterized, but the deletion of its paralog CEP170 is associated with seizures, microcephaly, and corpus callosum abnormalities. ${ }^{33}$ Given the number of recurrences and the extensive expression of $C E P 170 B$ in the brain, it is plausible that it may play a role in MTLE-HS pathogenesis.

We found a relatively high ratio of nonsynonymous to synonymous de novo variants, suggesting that de novo variants may be a contributing factor in the pathogenesis of MTLEHS. Notably, a number of the de novo variants identified overlap with those reported in previous family-based studies of neuropsychiatric disorders. In particular, among the 18 genes carrying the nonsynonymous de novo variants, 3 have been reported in ASD. These include the gain-of-function p.R451C mutation in the esterase domain of NLGN3 (Neuroligin 3). ${ }^{34}$ p.R451C mutant mice showed increased AMPA receptor-mediated excitatory synaptic transmission in the hippocampus, raising the amount of NMDA receptors by twofold. ${ }^{35}$ In our patient (no. 34), the de novo variant is also found within the esterase domain of NLGN3 (p.S499L). This adds further support to the hypothesis of shared biology between epilepsy and ASD. ${ }^{27}$

One of the patients was found to have a de novo mutation in GRASP. Relevant knockout rat models showed reduced dendritic outgrowth in immature hippocampal neurons. ${ }^{36}$ The p.N162S mutation carried by our patient maps to the PDZ domain of the GRASP protein, where it binds to mGluRs and gamma-aminobutyric acid B receptor 2 . Hence, altered GRASP function might affect the development of the hippocampus.

Our study has limitations. The sample size is relatively small, particularly the number of trios. Trios studies are challenging to perform in adults because of logistic reasons (e.g., parents often do not live with probands or unable to participate because of ill health). The possibility of additional extratemporal lobe seizures cannot be completely ruled out in all the patients. However, strict criteria were used to define MTLEHS, and nearly two-thirds of patients analyzed had histologic confirmation of HS. Parents or controls were not specifically screened for HS by MRI. However, parents or controls with epilepsy were excluded, and the prevalence of HS in people without epilepsy is rare. In a study of 207 patients who underwent high-resolution MRI for nonepilepsy indication (hearing loss), HS was found in 2, both had history of seizures. ${ }^{37}$ Hence the prevalence of HS in people without epilepsy is estimated to be less than $0.5 \%$.

This is a study specifically investigating rare variants and de novo variants associated with MTLE-HS, revealing complex genetic architecture. The findings provide further support to the involvement of the PI3K/Akt/mTOR pathway in the pathogenesis of MLTE, potentially via FMRP regulation, and shared pathobiology between epilepsy and other neuropsychiatric disorders. Collaboration effort to increase discovery 
Table 4 Genes carrying nonsynonymous de novo variants in probands of trios

\begin{tabular}{|c|c|c|c|c|c|c|c|}
\hline $\begin{array}{l}\text { Participant } \\
\text { no. }\end{array}$ & Gene & $\begin{array}{l}\text { Variant } \\
\text { type }\end{array}$ & Chr & Position & Change & $\begin{array}{l}\text { ExAC } \\
\text { frequency }\end{array}$ & Mouse phenotype \\
\hline 9 & FAM65A & M & 16 & 67574094 & g.595C>T:p.R199C & $8.3 \times 10^{-6}$ & NA \\
\hline 12 & $F G B$ & M & 4 & 155491720 & g.1394T>C:p.V465A & 0 & NA \\
\hline 12 & MASTL & M & 10 & 27459014 & g.1126A>T:p.S376C & 0 & $\begin{array}{l}\text { Abnormal embryonic neuroepithelium } \\
\text { morphology }\end{array}$ \\
\hline 12 & CEP170B & M & 14 & 105353332 & g.2756C>T:p.T919M & $1.7 \times 10^{-5}$ & NA \\
\hline 19 & SLC5A12 & $M$ & 11 & 26743102 & g.160G>C:p.G54R & 0 & $\begin{array}{l}\text { Abnormal neuron differentiation, abnormal } \\
\text { excitatory postsynaptic potential, reduced long } \\
\text { term potentiation }\end{array}$ \\
\hline 19 & GRASP & $\mathrm{M}$ & 12 & 52407501 & g.56A>G:p.N19S & 0 & $\begin{array}{l}\text { Abnormal neuron differentiation, abnormal } \\
\text { excitatory postsynaptic potential, reduced long } \\
\text { term potentiation }\end{array}$ \\
\hline 19 & $C D C 42 E P 1$ & $\mathrm{~F}$ & 22 & 37962638 & g.283delG:p.P95fs & 0 & NA \\
\hline 24 & NBEAL1 & M & 2 & 203921179 & g.335C>G:p.T112S & 0 & NA \\
\hline 26 & $N P C 1 L 1$ & M & 7 & 44578845 & g.1151C>T:p.S384L & $4.9 \times 10^{-5}$ & NA \\
\hline 30 & ANXA6 & M & 5 & 150481051 & g.1980C>G:p.D660E & 0 & Increased ventricle muscle contractility \\
\hline 34 & NLGN3 & M & $\mathrm{x}$ & 70387443 & g.1496C>T:p.S499L & 0 & $\begin{array}{l}\text { Abnormal CNS synaptic transmission, decreased } \\
\text { brain size, abnormal nervous system } \\
\text { development }\end{array}$ \\
\hline 37 & SBSPON & M & 8 & 74005154 & g.149G>T:p.C50F & 0 & NA \\
\hline 39 & RASEF & M & 9 & 85615372 & g.1551G>T:p.K517N & 0 & NA \\
\hline 39 & BAIAP2 & M & 17 & 79090095 & g.1649C>T:p.A550V & 0 & Abnormal CNS synaptic transmission \\
\hline 40 & ROBO4 & $\mathrm{s}$ & 11 & 124763780 & g.1480C>T:p.R494* & $5.3 \times 10^{-5}$ & Abnormal telencephalon development \\
\hline 43 & PLEC1 & M & 8 & 144998224 & g.5954C>T:p.T1985M & 0.0004 & Decreased nerve conduction velocity \\
\hline 43 & TACC2 & M & 10 & 123842395 & g.380C>T:p.A127V & $1.6 \times 10^{-5}$ & NA \\
\hline 44 & BHLHE40 & M & 3 & 5024745 & g.607G>A:p.E203K & 0 & $\begin{array}{l}\text { Increased susceptibility to pharmacologically } \\
\text { induced seizures }\end{array}$ \\
\hline
\end{tabular}

Abbreviations: ExAC = Exome Aggregation Consortium; $F=$ frameshift; $M=$ missense; $N A=$ not available; $S=$ stop-gain.

Bold: the same gene reported by other de novo variants studies. 1: epileptic encephalopathies, 2: autism spectrum disorder, and 3: schizophrenia.

power and different types of genetic abnormalities (copy number variations $[\mathrm{CNVs}]$, methylation) and analysis of the resected hippocampal tissues to identify somatic mutations may further improve our understanding of the pathogenesis of this genetically heterogeneous disorder, potentially leading to novel therapeutic targets.

\section{Author contributions}

J.K.L. Wong and H. Gui performed data analysis and prepared the manuscript. M. Kwok performed laboratory work and collected data. P.W. Ng and C.H.T. Lui collected data and provided and cared for study patients. L. Baum advised on data analysis and prepared the manuscript. P.C. Sham served as a scientific advisor. P. Kwan advised on data analysis, prepared the manuscript, and served as a scientific advisor. S.S. Cherny supervised the project, advised on data analysis, prepared the manuscript, and served as a scientific advisor.

\section{Acknowledgment}

The authors thank all patients, their families, and all healthy controls for their participation.

\section{Study funding}

This research was supported by the Hong Kong University Grants Council General Research Fund Grant HKU 7630/ $12 \mathrm{M}$ (PI: SSC).

\section{Disclosures}

J.K.L. Wong, H. Gui, and M. Kwok report no disclosures. P.W. $\mathrm{Ng}$ serves or has served on the editorial board of Cerebrovascular Diseases, Journal of Neurologic Sciences, and Hong Kong Medical Journal. C.H.T. Lui reports no disclosures. L. Baum has received research support from the Chinese University of Hong Kong, St. Paul Co-educational College, and University of Macau; and holds a patent regarding nanoparticles for Alzheimer's disease screening by MRI. P.C. Sham serves or 
has served on the editorial board of Human Heredity and has received research support from the RGC General Research Fund GRF, RGC Collaborative Research Fund (CRF), and NSFC/RGC Joint Research Scheme. P. Kwan serves or has served on scientific advisory boards of Eisai and UCB Pharma; has received funding for travel and/or speaker honoraria from UCB Pharma, Novartis, and Eisai; and has received research support from Eisai, UCB Pharma, Australia Research Council, Australian National Health \& Medical Research Council, National Science Foundation of China, and Bill \& Melinda Gates Foundation. S.S. Cherny has received funding for travel and/or speaker honoraria from the University of Colorado; serves or has served on the editorial board of Behavior Genetics, PLOS One, PeerJ, and Journal of Child Psychology er Psychiatry; and has received research support from University Grants Council (Hong Kong)/General Research Fund (GRF). Full disclosure form information provided by the authors is available with the full text of this article at Neurology.org/NG.

Received November 10, 2017. Accepted in final form April 13, 2018.

\section{References}

1. Falconer MA, Serafetinides EA, Corsellis J. Etiology and pathogenesis of temporal lobe epilepsy. Arch Neurol 1964;10:233-248.

2. Thom M, Martinian L, Catarino C, et al. Bilateral reorganization of the dentate gyrus in hippocampal sclerosis: a postmortem study. Neurology 2009;73:1033-1040.

3. Kwan P, Schachter SC, Brodie MJ. Drug-resistant epilepsy. N Engl J Med 2011;365: 919-926.

4. Jehi L, Friedman D, Carlson C, et al. The evolution of epilepsy surgery between 1991 and 2011 in nine major epilepsy centers across the United States, Germany, and Australia. Epilepsia 2015;56:1526-1533.

5. International League Against Epilepsy Consortium. Genetic determinants of common epilepsies: a meta-analysis of genome-wide association studies. Lancet Neurol 2014;13:893.

6. Cavalleri GL, Lynch JM, Depondt C, et al. Failure to replicate previously reported genetic associations with sporadic temporal lobe epilepsy: where to from here? Brain 2005; $128: 1832-1840$.

7. Kasperavičiūte D, Catarino CB, Matarin M, et al. Epilepsy, hippocampal sclerosis and febrile seizures linked by common genetic variation around SCN1A. Brain 2013;136: 3140-3150.

8. Vonberg FW, Bigdeli TB. GEnetic correlation between schizophrenia and epilepsy. JAMA Neurol 2016;73:125-126.

9. Thomas RH, Berkovic SF. The hidden genetics of epilepsy-a clinically important new paradigm. Nat Rev Neurol 2014;10:283-292.

10. Allen AS, Bellows ST, Berkovic SF, et al. Ultra-rare genetic variation in common epilepsies: a case-control sequencing study. Lancet Neurol 2017;16:135-143.

11. Androsova G, Krause R, Borghei M, et al. Comparative effectiveness of antiepileptic drugs in patients with mesial temporal lobe epilepsy with hippocampal sclerosis. Epilepsia 2017;58:1734-1741.

12. Li Y, Samartzis D, Campbell DD, et al. Two subtypes of intervertebral disc degeneration distinguished by large-scale population-based study. Spine J 2016;16:1079-1089.
13. Benjamini Y, Hochberg Y. Controlling the false discovery rate: a practical and powerful approach to multiple testing. J Royal Stat Soc Ser B (Methodological) 1995: 289-300.

14. Li MX, Gui HS, Kwan JS, Bao SY, Sham PC. A comprehensive framework for prioritizing variants in exome sequencing studies of Mendelian diseases. Nucleic Acids Res 2012;40:e53.

15. Perucca P, Scheffer IE, Harvey AS, et al. Real-world utility of whole exome sequencing with targeted gene analysis for focal epilepsy. Epilepsy Res 2017;131:1-8.

16. Hellwig S, Mamalis P, Feige B, Schulze-Bonhage A, van Elst LT. Psychiatric comorbidity in patients with pharmacoresistant focal epilepsy and psychiatric outcome after epilepsy surgery. Epilepsy Behav 2012;23:272-279.

17. Purcell SM, Moran JL, Fromer M, et al. A polygenic burden of rare disruptive mutations in schizophrenia. Nature 2014;506:185-190.

18. Iossifov I, Ronemus M, Levy D, et al. De novo gene disruptions in children on the autistic spectrum. Neuron 2012;74:285-299.

19. Callan MA, Zarnescu DC. Heads-up: new roles for the fragile X mental retardation protein in neural stem and progenitor cells. Genesis 2011;49:424-440.

20. Ascano $\mathrm{M} \mathrm{Jr}$, Mukherjee $\mathrm{N}$, Bandaru $\mathrm{P}$, et al. FMRP targets distinct mRNA sequence elements to regulate protein expression. Nature 2012;492: 382-386.

21. Darnell JC, Van Driesche SJ, Zhang C, et al. FMRP stalls ribosomal translocation on mRNAs linked to synaptic function and autism. Cell 2011;146:247-261.

22. Francioli LC, Menelaou A, Pulit SL, et al. Whole-genome sequence variation, population structure and demographic history of the Dutch population. Nat Genet 2014; 46:818.

23. Landrum MJ, Lee JM, Riley GR, et al. ClinVar: public archive of relationships among sequence variation and human phenotype. Nucleic Acids Res 2014;42: D980-D985.

24. Fromer M, Pocklington AJ, Kavanagh DH, et al. De novo mutations in schizophrenia implicate synaptic networks. Nature 2014;506:179-184.

25. Epi KC, Epilepsy Phenome/Genome P, Allen AS, et al. De novo mutations in epileptic encephalopathies. Nature 2013;501:217-221.

26. Iossifov I, O’Roak BJ, Sanders SJ, et al. The contribution of de novo coding mutations to autism spectrum disorder. Nature 2014;515:216-221.

27. Lee BH, Smith T, Paciorkowski AR. Autism spectrum disorder and epilepsy: disorders with a shared biology. Epilepsy Behav 2015;47:191-201.

28. Ouwenga RL, Dougherty J. Fmrp targets or not: long, highly brain-expressed genes tend to be implicated in autism and brain disorders. Mol autism 2015;6:16.

29. Sosunov AA, Wu XP, McGovern RA, et al. The mTOR pathway is activated in glial cells in mesial temporal sclerosis. Epilepsia 2012;53:78-86.

30. Xiao Z, Peng J, Yang L, Kong H, Yin F. Interleukin- $1 \beta$ plays a role in the pathogenesis of mesial temporal lobe epilepsy through the PI3K/Akt/mTOR signaling pathway in hippocampal neurons. J Neuroimmunol 2015;282:110-117.

31. Yang XY, Zhou XY, Wang QQ, et al. Mutations in the COPII vesicle component gene SEC24B are associated with human neural tube defects. Hum Mutat 2013;34: 1094-1101.

32. Schmidt T, Samaras P, Frejno M, et al. ProteomicsDB. Nucleic Acids Res 2018;46: D1271-D1281.

33. Hill $\mathrm{AD}$, Chang $\mathrm{BS}$, Hill $\mathrm{RS}$, et al. A 2-Mb critical region implicated in the microcephaly associated with terminal 1q deletion syndrome. Am J Med Genet A 2007;143: $1692-1698$.

34. Jamain S, Quach H, Betancur C, et al. Mutations of the X-linked genes encoding neuroligins NLGN3 and NLGN4 are associated with autism. Nat Genet 2003;34: 27-29.

35. Etherton M, Foldy C, Sharma M, et al. Autism-linked neuroligin-3 R451C mutation differentially alters hippocampal and cortical synaptic function. Proc Natl Acad Sci USA 2011;108:13764-13769.

36. Mo J, Choi S, Ahn PG, Sun W, Lee HW, Kim H. PDZ-scaffold protein, Tamalin promotes dendritic outgrowth and arborization in rat hippocampal neuron. Biochem Biophys Res Commun 2012;422:250-255.

37. Moore KR, Swallow CE, Tsuruda JS. Incidental detection of hippocampal sclerosis on MR images: is it significant? Am J Neuroradiol 1999;20:1609-1612. 


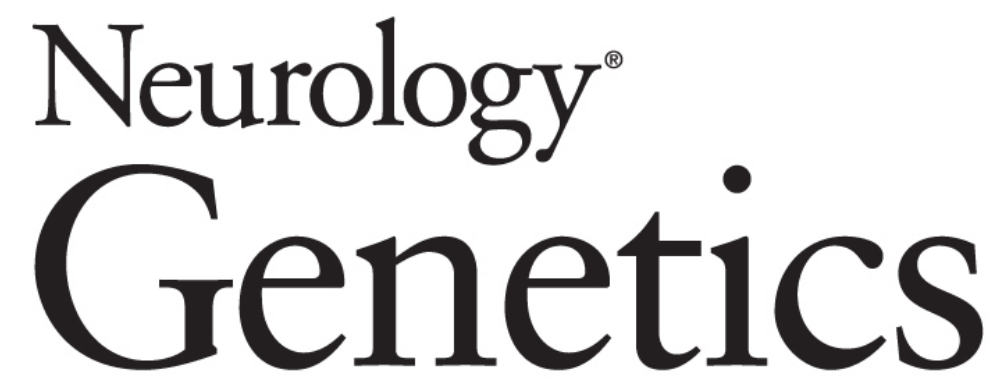

Rare variants and de novo variants in mesial temporal lobe epilepsy with hippocampal sclerosis

John K.L. Wong, Hongsheng Gui, Maxwell Kwok, et al. Neurol Genet 2018;4;

DOI 10.1212/NXG.0000000000000245

This information is current as of June 11, 2018

Neurol Genet is an official journal of the American Academy of Neurology. Published since April 2015, it is an open-access, online-only, continuous publication journal. Copyright Copyright ( 2018 The Author(s). Published by Wolters Kluwer Health, Inc. on behalf of the American Academy of Neurology.. All rights reserved. Online ISSN: 2376-7839.

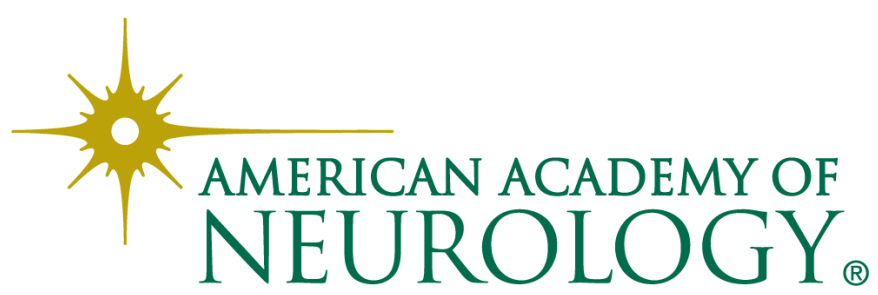




\section{Updated Information \& Services}

References

Citations

Subspecialty Collections

Permissions \& Licensing

Reprints including high resolution figures, can be found at: http://ng.neurology.org/content/4/3/e245.full.html

This article cites 36 articles, 2 of which you can access for free at: http://ng.neurology.org/content/4/3/e245.full.html\#\#ref-list-1

This article has been cited by 3 HighWire-hosted articles: http://ng.neurology.org/content/4/3/e245.full.html\#\#otherarticles

This article, along with others on similar topics, appears in the following collection(s):

All Epilepsy/Seizures

http://ng.neurology.org//cgi/collection/all_epilepsy_seizures Association studies in genetics

http://ng.neurology.org//cgi/collection/association_studies_in_genetics Hippocampal sclerosis

http://ng.neurology.org//cgi/collection/hippocampal_sclerosis

Information about reproducing this article in parts (figures,tables) or in its entirety can be found online at:

http://ng.neurology.org/misc/about.xhtml\#permissions

Information about ordering reprints can be found online:

http://ng.neurology.org/misc/addir.xhtml\#reprintsus

Neurol Genet is an official journal of the American Academy of Neurology. Published since April 2015, it is an open-access, online-only, continuous publication journal. Copyright Copyright $\odot 2018$ The Author(s). Published by Wolters Kluwer Health, Inc. on behalf of the American Academy of Neurology.. All rights reserved. Online ISSN: 2376-7839.

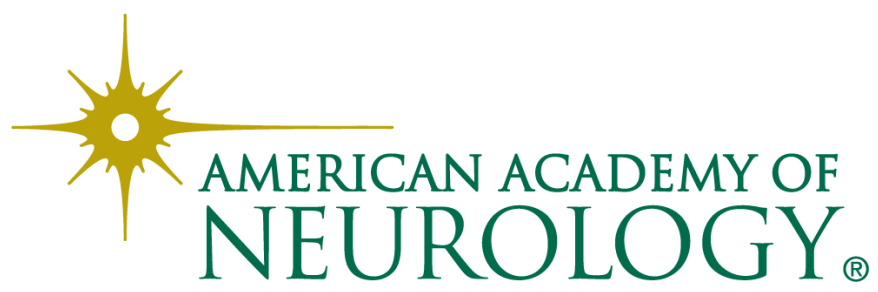

